\title{
Weapons of Mass Destruction
}

\author{
Ananda Majumdar \\ University of Alberta, Antarctic Institute of Canada
}

This journal is licensed under a Creative Commons Attribution-NonCommercial 4.0 International License (CC-BY-NC).

Articles can be read and shared for noncommercial purposes under the following conditions:

- BY: Attribution must be given to the original source (Attribution)

- NC: Works may not be used for commercial purposes (Noncommercial)

This license lets others remix, tweak, and build upon your work non-commercially, and although their new works must also acknowledge you and be non-commercial, they don't have to license their derivative works on the same terms. License Deed Link: http://creativecommons.org/licenses/by-nc/4.0/

Legal Code Link: http://creativecommons.org/licenses/by-nc/4.0/legalcode

$A B C$ Research Alert uses the CC BY-NC to protect the author's work from misuse.

\section{Abstract}

From the perspective of WMD, the purpose of this essay is to explore and understand the violence of the world in the past and at present, discovers ways to reduce violence for the global development. Global development or International development is an interesting topic in Political Science and or International Relations and my favorite therefore I would like to do further studies as $\mathrm{PhD}$ as my preparation to gain knowledge and experience. Chemical Weapon, Biological Weapon are not recognized as modern weaponries while various nuclear, thermonuclear and radiological weapons are modern weaponries. Yet recent killing of North Korean President's step brother in Malaysia Airport by Nerve gas reminds that Chemical weapons still exists and used by countries who are not signatory of the convention. In Syria chemical weapon is using currently.

Keywords

Explosive device, ICBM, IRBM, SRBM, Mustard agent, Plague, Manhattan project, B52, Anti satellite Missile, Trident missile, Agni series, Dong Feng series, Nuclear deterrent, Convention of biological and chemical warfare, Cold war, World War 1 \&2, Post Cold war, CTBT, NPT, NSG, OPCW

\section{Introduction}

A weapon of mass destruction is a conventional, nuclear, chemical, biological, satellite, cyber, virus, lasers, radiological that can demolish cities, areas, and human being caused a universal destruction. Cosmo Gordon Lang of Canterbury firstly used the term Weapons of Mass Destruction in 1937 during the period of aerial bombardment in Guernica, Spain. In World War 1, countries used chemical and biological weapon and nuclear weapons still did not invent. Before World War 1, it recognized as conventional weapons or war but following the atomic bombings of Hiroshima and Nagasaki that ended World War 2 and the period of ideological differences, which also recognized as cold war between The USSR and The USA used as non-conventional weapons. 


\section{LITERATURE REVIEW}

powerful countries are producing nuclear weapons, radiological weapons, hydrogen weapons, hiding information of chemical weapon, biological weapon and many more it is their power muscle to show rest of the world, it is their prestige but they are forgetting that the world does not need to eliminate by several weapons then why is there huge investment instead global development by eliminating hunger, eliminating issues of mental health, purification of climate etc. Weapons of mass destruction can not develop the world that we human being want, it brings war, however in such a situation deterrent theory can be useful and can be a part of global development by control of warfare.

\section{METHODOLOGY}

As an article researcher at Antarctic Institute of Canada, I choose this topic under peace, violence and conflict areas for my further $\mathrm{PhD}$. I read those online articles and Wikipedia and wrote through my own words based in their information; I collected information from websites, collected information from online articles. After 3 times edition by writing, I made my final manuscript draft for final presentation.

\section{RESULTS AND DISCUSSION}

A weapon of mass destruction is a conventional, nuclear, chemical, biological, satellite, cyber, virus, lasers, radiological that can demolish cities, areas, and human being caused a universal destruction. Cosmo Gordon Lang of Canterbury firstly used the term Weapons of Mass Destruction in 1937 during the period of aerial bombardment in Guernica, Spain. In World War 1, countries used chemical and biological weapon and nuclear weapons still did not invent. Before World War 1, it was recognised as conventional weapons or war but following the atomic bombings of Hiroshima and Nagasaki that ended World War 2 and the period of ideological differences, which also recognized as cold war between The USSR and The USA was used as non-conventional weapons. William Safire firstly introduced a word by investigation in Russian language - oruzhiye massovogo porazheniya that is weapons of mass destruction in English. There were two other persons that involved finding out this word by investigation were James Goodbye and Bernard Barush.

In January 1946 in London, it used a wording the elimination from national armaments of atomic weapon and of all another weapons adaptable to mass destruction. The commission created the Atomic Energy Commission, which transform in to International Atomic Energy Agency (IAEA). During the Cold War era weapons of mass destruction refers nuclear weapons, which was the strategic weapons of the United States against Former Soviet Union as nuclear deterrent to survive the US from any kind of conventional or nuclear attack by the USSR under Mutual Assured Destruction. It was the Israeli Air force that destroyed Iraqi pre-operational nuclear reactor to save Israel from Iraqi nuclear weapons and the Israeli Prime Minister Menachem Begin stated to destroy all of the efforts of Iraqi nuclear weapons of mass destruction in advance to save Israel and Israeli from action of Iraq in the future, his policy of pre-emptive action against real or perceived weapons of mass destruction become known as the Begin Doctrine.

Many US Presidents such as Ronald Reagan use the term weapons of mass destruction in Reykjavik Iceland summit in 1986 during his speech on outer space treaty, then President 
George W. Bush senior in 1989 during his speech to the United Nations on chemical arms. The Cold War era was highly tensed due to the US and The USSR's weapons of mass destruction, and the division of two most antagonist blocks such as western block was capitalist countries led by the USA and eastern block was socialist countries led by the USSR. Both the super powers had stockpiles of chemical weapons and biological weapons, chlorine gas, which is a choking agent, and mastered gas which is a blistering agent were fired against the troops during world war1 (1914-18) and in 1980-88 Iran-Iraq war, on the side biological weapons is an infectious agents such as bacteria, viruses burst over populated areas cause might be less but severe outbreak of deadly diseases such as anthrax, plague, small pox etc. though chemical weapons used in 80's but there was no use of biological weapons after world war 2 .

It was Japan that used biological weapons during World War 2 by spreading plague -infected lice over China. Chemical and biological weapons can be produced and utilized anywhere anytime by the terrorist groups and it might be the choice of their weapons. Stopping such dangerous efforts by terrorist there was convention of nuclear non-proliferation treaty (1968), convention of biological weapons (1972) and the convention of chemical weapons (1993). Collapse of Soviet Union in 90's changed everything and the new world order establish as multipolar world where four to five countries rises as the most powerful countries and the fear of weapons of mass destructions spreads among those countries beyond the USA and Russia. However, fall of Soviet Union also reduced the US reliance on nuclear war as a deterrent and to focus on disarmament.

In 1990 Iraq, invaded Kuwait and thirty-four nations led by the US involved in war against Iraq in response to Iraq's invasion of Kuwait. The Gulf War crisis again raised the question on weapons of mass destruction and Iraq's intentions. The US administration gave priority to destroy any type of adventurism of Iraq on nuclear, biological and chemical weapons. After the 11 September 2001, attacks and the 2001 anthrax attacks in the United States fear of nonconventional weapons and asymmetrical warfare increased in many countries and all over the world. American forces attacked on Iraq to destroyed all of its weapons arsenals but found none. In 2009, Iraq declared stockpile of chemical weapons that mainly contained chemical precursors, but some warhead remains usable.

Chemical weapons referred as toxic chemical that is used for arms production, and used in First World War. It is categorized as choking agents such as chlorine, phosgene, blister agents such as mustard and lewisite, blood agents such as hydrogen cyanide, nerve agents such as sarin, soman etc.

Chemical are considered as chemical weapons when it is produced and stockpiled in amount that exceed requirements for those purposed that is not prohibited under the convention. The convention of chemical weapons (1993) is the most recent arms control agreement with the force of international law confirmed that toxic of chemicals will be used for purposes that is not connected with any type of weapons because of ban on the production, stockpiling and use of chemical weapons. OPCW (Organization for the Prohibition of Chemical weapons) has mandate to monitor chemical industry for its security whether the company is making bomb or not through their toxic materials. 
The United States of America, Russia and North Korea conformed to have remaining CW stockpile in 2015 while India confirmed the United Nations about the complete destruction of stockpile of CW, Iraq used chemical weapons massively during Iran-Iraq war against Iran and used mustard gas in an attack against Kurdish People; however Government of Iraq finally declared stockpiles of CW and join CWC. Japan also destroyed completely their mustard gas-lewisite mixture CW by using mobile destruction facility by September 2010 . Libya used mustard gas as chemical weapons under Gaddafi regime against Chad; however, post Gaddafi National Transitional Council is co-operating with OPCW regarding the destruction of chemical weapons. Russia has widely destroyed CW as of 2016; it destroyed $94 \%$ of chemical weapons and planning to destroy completely by 2018 .

The United States of America stored it's CW within the Continental United States (CONUS), they are Tooele Army Depot, Utah approximately $43 \%$ of its largest stockpile, Pine bluff Arsenal, Arkansas approximately 12\%, Umatilla Depot Activity, Oregon approximately 11.6\%, Oueblo Depot Activity, Colorado approximately 9.9\%, Anniston Army Depot, Alabama approximately 7.1\%, Aberdeen Army Ammunition Plant, Indiana approximately 3.9\%, Aberdeen Proving Ground, Maryland, approximately 5\%, Blue Grass Army Depot, Kentucky approximately $1.6 \%$. Remaining's been located on Johnston Atoll in the Pacific Ocean. Stockpile is eliminating and by 2017 it has chance full elimination. Countries are Israel and North Korea are not officially bounded by CWC and therefore it is unclear about their stand on elimination of chemical weapons.

North Korea is only country in the world that has huge amount of stockpiles approximately 5000 tones including mustard gas, sarin, and nerve agents. Germ weapon is biological weapon may be utilized as weapons against human by agents such as bacteria, viruses, fungi, toxins etc. In 2013180 countries had signed the Biological Weapons Conventions (BWC) to eliminate those weapons and from developing, testing, stockpiling or deploying them. Bacteria which is single cell organism cause diseases such as anthrax, plague etc., viruses which is much smaller than bacteria cause disease such as Venezuelan equine encephalitis (disease of horse can be affected human as well), fungi cause such disease such as rice blast, plants etc., mainly use against corps. So these are used as biological weapons against human, plants, etc.

Weaponized lethal biological agents are intended to delivered as dust in the air, which is aerosols and can cause infections when breathed by targeted persons; however musk that is equipped with filters capable of blocking bacteria, viruses, can protect personnel to escape from biological warfare. During World War 1 Japan used this weapon against Chinese and experimented on various agents by killing 3000 humans including prisoners. The USA, Russia, Germany and the UK had their laboratory for this weapon research and development, but Japan was only country that used Botulinum category $\mathrm{C}$ bacteria as bio weapon against Chinese during occupation of Manchuria. During Cold war The USSR yet a signatory of $\mathrm{BWC}$, conducted several research of biological weapons and violated the rules to use against

The USA, however after fall of Soviet Union both The USA and Russia worked together to reduce this weapon from Russia. However still it is doubtful that whether countries are not producing or stockpiling biological weapon as it can be easily hide, rather than countries terrorist organizations such as Al-Qaeda showed interest on this weapon and operated an anthrax laboratory in Afghanistan and in 2001 anthrax-laden letters were sent to many 
politicians and prominent people in the United States killing 5 people and 22 hospitalized. Bacillus Anthracis bacteria which is an anthrax is one of the deadliest agents to be used as biological weapon identified by US centre for Disease Control and Prevention as category A agent, a significant danger to national security, this gram positive rod shaved anthrax spores are found naturally in soil which can be produced in a laboratory and last for a long time.

Botulinum toxin is another dangerous bacteria with four forms such as food borne, infant, wound, and animal can be produced easily and can used as bio weapons by aerosol; it can kill a million people if inhaled. Those bacteria are found in forest soil, lakes, streams, and the intestinal tracts of some fish and animals. Variola major a virus causes small pox, which has no cure and can be prevented by vaccination. It was used against indigenous Americans and in Americans Revolutionary War. Francisella tularensis a virus cause's small pox can be used as bio weapon, symptoms like vomiting, fever, cough, diarrhoea. This virus is category an agent. Ebola virus disease is deadly one induced by infection with Ebola virus forms was discovered in 1976 in the Democratic Republic of Congo, it came transmitted to human from animal and can be a dangerous biological weapon because of its fatality. Yersinia pestis is another form of bacteria causes plague can be produced in laboratory as biological weapon. It can be spread from persons to person's symptoms like fever, weakness etc. if not treated properly infected person must be died. Marburg is a fever caused by Mart burg virus includes Ebola virus as well, it can be used as biological weapon because of its massive fatality approximate $90 \%$ experimented by Soviet scientists.

Bunya virus caused Korean Hemorrhagic fever during Korean War and approximately 3000 American and Korean soldiers became infected; however, no evidence was found as use of this virus as biological weapon. Soviet and Japanese scientists experimented most of the virus and bacteria for its utilization as biological weapon. Misuse of science to create biological and chemical weapons that is poison and expanded disease all over the world which does not comply border has been provoked by public mind but the using of poisonous weapons in world war 1 caused to make an agreement which is Geneva Protocol 1925 for banning poisonous weapons to use warfare as a result during world war 2 no country used biological and chemical weapons due to fear of using each other, it was the respect of the agreement as well.

The protocol was a landmark for international humanitarian law and transferred into conventions adopted by countries in 1972 and in 1993. As I said earlier, it was the convention of biological weapons in 1972 where countries were agreed to eliminate their weapons including its development, stockpiling, retention, transfer, delivery system etc. In 1993 there was another agreement adopted by countries over the banning of chemical weapons just like biological weapons. Convention of poisonous weapons did not ban on tear gas for law enforcement including domestic riot control purpose.

A nuclear weapon is an explosive device that extends its destructive force from fission bomb or thermonuclear bomb. Thermonuclear bomb is the most dangerous weighting more than 2400 pounds produces explosive force comparable to the detonation of more than 1.2 million tons of TNT. Nuclear bomb can destroy an entire city by one blast. Near the end of World War 2, the United States dropped Little Boy over Hiroshima and Fat Man over Nagasaki in 
Japan in reply of Japan's Paarl Harbour attack in the United States and that was the first time use of nuclear weapon in the ware fare. After Hiroshima and Nagasaki, incident nuclear bomb has been modernized by countries such as the USA, Russia, China, India, Britain, France, Pakistan, North Korea and Israel. Germany, Italy, and the Netherlands are nuclear weapons sharing countries. South Africa is only country in the world that stated their nuclear program independently and announced to close the program as well.

Fusion bomb is the combination of the nuclei of two atoms makes a heavier single atom, at extremely high temperature the nuclei of hydrogen isotopes deuterium and tritium can readily fuse and releases enormous amounts of energy. In fission bomb, fuel must be kept in subcritical masses, where as critical mass is the minimum mass of fissionable material required sustaining a nuclear fission reaction. Fusion bomb is called as hydrogen or thermonuclear weapon and modern days nuclear weapon is thermonuclear weapon due to its more efficient, countries like USA, Russia, China, Britain, France, India and North Korea have such thermonuclear weapon through it is controversial for India and North Korean thermonuclear weapon test. There are other types of nuclear bomb such as boosted fission weapon that increases its explosive yield through a small amount of fusion reaction but it is not fusion but fission type of bomb, boosted fission bomb is divided by internally boosted and externally boosted and all it's materials are set up on both internally and externally boosted sides.

A neutron bomb is a thermonuclear bomb yields a small explosion but large portion of neutron radiation. Salted bomb is a radiological weapon can produce large quantities of long-lived radiological contamination, salted bomb is dangerous such a dooms day bomb because of its exceptional quantities of radio activities with half lives of decades as it goes up to stratosphere where wind currents would distribute it around the world would make devastation of entire human civilization. Aircraft can deliver nuclear bomb as the traditional way that countries discovered. Currently thorough long range (ICBM), medium range (IRBM) and short-range ballistic missile nuclear warhead can be dropped any part of the world and these ballistic missile can be deployed through nuclear powered submarine, diesel powered submarine (SLBM), through bomber aircraft, through land based canister etc. More advanced system is called multiple independently targetable re-entry vehicle (MIRV) that can launch multiple warheads at different targets by one missile reducing the chance of missile defence system.

Tactical weapon is a modern type of nuclear weapon destroys a small or limited areas etc. The United States of America was the first country that discovers nuclear weapon by explosion on $16^{\text {th }}$ of July 1945 called The Trinity test under Manhattan project, US nuclear weapon development was the fear of Nazi Germany and then used the bomb at Nagasaki and Hiroshima, Japan during the end part of world war. Little Boy was dropped over the city of Hiroshima with energy of 15 kiloton of TNT (TNT is high exclusive form made by three hydrogen atom, it is relatively insensitive to shock and can be conveniently melted) destroyed approximately 50,000 buildings and killed approximately 70,000 people including Japanese combatants and Korean slave labour. Fat man was dropped over the city of Nagasaki with the energy of 20 kiloton killed approximately 35000 people and destroyed $60 \%$ of the city. From 1945 to 1990 more than 70,000 warheads were developed in various forms from .01 kiloton to the 25-megaton (US B41 is the most dangerous nuclear weapon which is 25 megaton). Post cold war period US is different and reduces stockpile of warheads, ceasing 
production of nuclear weapon, shutdown of nuclear research centre, plant etc. Through reducing of nuclear warheads US wants to make a less risk world and it maintains an arsenal of over 7,200 nuclear bombs, 2000(1900 were deployed as strategic and 180 non strategic).

The United States tested nuclear weapon several times some of them are; Trinity test (July 1945), Operation Crossroad (July 1946), Operation Greenhouse (May 1951), Ivy Mike Shot (November 1952), Castle Bravo Shot (March 1954), Operation Argus(August 1958), Operation Dominic(May 1962), Operation Storax (July 1962) and many more test through land based ballistic missile and submarine based ballistic missile. US developed its weapons delivery system systematically; it was first through bomber planes, and then created rocketry system such as MGR-1 Honest John was the first surface-to-surface $24 \mathrm{~km}$ missile in 1953. B29 Super fortress was one of their long-range bombers that were developed during cold war period.

During 50's and 60's decades US elaborate computerized early warning system to detect incoming Soviet missile and to response immediately by coordination of every departments. During the same period, US developed intercontinental ballistic missile to attack over Russia and other place of mid-America and other parts of the world. US developed MIRV program from 1970's to 80's decades. Today's USA is the super power in arms and arsenals, as parts of its nuclear triad it maintains approximately 94 nuclear capable bomber (B-2s, B-52s), over 400 Minuteman 3 ICBM and 12 Ohio-class ballistic missile submarines. America's Trident 2 missile can destroys the target almost 100\% accurate; USA maintains B61 12 and B83 nuclear bombs are the most dangerous weapon with 50 kilotons and 1.2 megaton and reliable of its accuracy.

During World War 1 USA produced mustard gas, phosgene gas as it's chemical weapon, it also began production of lewisite gas, during World War 2 chemical weapons were not used by the US and it's other allies but were deployed to Europe because of Nazi Germany. During cold war period US troops kept chemical weapons as defense but never used though it was claimed by China, North Korea and Russia that US used chemical weapon during Korean war and Vietnam war but it had no evidence, furthermore in 1991 former President George H.W. Bush declared to destroying all chemical weapon agent and it is almost $90 \%$ done, complete destruction of chemical weapon is not expected until 2023. Soviet Union started its nuclear program in World War 2 after discovery of US-British and Canadian project.

After bombing of Hiroshima and Nagasaki Soviet stared to expand the research on nuclear weapons. Soviet Union first conducted nuclear explosion in 1949 with yield of 22 kiloton named RDS-1 an implosion type just like US Fat Man made the USSR the second after the USA to detonate a nuclear device. Soviet Union made 400 kiloton RDS-6S and detonated in 1953 a ten times more powerful then RDS-1. The RDS-37 tested in November 1955 with a yield of 1.6 megaton which is 100 times powerful than RDS-1. RDS_1 in 1949, RDS-2 in 1951, RDS-3 in 1951, RDS-4 in 1954, RDS-5, RDS-6 as hydrogen bomb in 1953, RDS-9 in 1955, RDS 37 a hydrogen bomb as megaton range in 1955, RDS-220 with yield of 50 megaton in 1961, Chagan in 1965 were those Soviet nuclear test which made the USSR as competitor of the USA and thus started cold war period through extensive tension between two superpowers. 
After fall of Soviet Union, Soviet nuclear weapons were deployed in Russia, Belarus, Kazakhstan, and Ukraine. In 1992 four states signed the Lisbon protocol to join the NPT (Nuclear Non-proliferation Treaty). As per Federation of American Scientists report Russia has approximately 4490 nuclear warheads where 1790 warheads are active strategic nuclear warheads, Russia has 1500 tactical nuclear weapons( non-strategic weapon used in battle field in military situations but not in enemy property, over tie city). Russia's modern nuclear weapons are RS-28 Sarmat(Satan 2 named by NATO) MIRV based ICBM allowed 10 heavy or 15 light warheads in one missile, one of the dangerous intercontinental ballistic missile in the world. Russian military doctrine announced to use its nuclear weapon against of any country who will create threat for Russia and its allies by nuclear or conventional weapons. Yet a signatory of NPT and CTBT Russia is developing its nuclear arsenals since 1997. There is an allegation that because of Russian contribution North Korea developed its nuclear weapon program. Britain is the third country in the world after the USA; Russia conducted its first nuclear device in October 1952, conducted first thermonuclear test in May 1957. Britain last nuclear test was in November 1991 before the signatory of CTBT and NPT. Since 1952 to 1991, Britain conducted 45-detonation test and currently has stockpiles of 215 warheads.

The United Kingdom has four vanguard class submarines armed with trident ICBM's missile and permitted USA to deployed its nuclear missile in UK's land. During the World War 2, British scientists studied on bio weapons including a test on the Scottish island using anthrax. Operation vegetarian was to be used on the event of Germany's anthrax attack over the United Kingdom. Offensive weapons such as Plague, brucellosis, vaccinia viruses developed continuously. Britain was a signatory country of the Hague convention in 1899 and 1907 but Germans retaliations of chlorine gas over British army forced to Britain to use chemical weapons in World War 1. British army deployed chlorine themselves for the first time during the battle of Loos in September 1925, by the end of the war, poison gas widely spread both sides, and a quarter of artillery shells were filled with gas and Britain had produced 25400 tons of toxic chemicals.

Royal Air force dropped mustard gas on Bolshevik troops in 1919. Britain has long history of using chemical and bio weapons over its enemy in Europe. France conducted first nuclear device in February 1960 followed by the British nuclear weapon program, then in August 1968 it conducted thermonuclear weapon test with yield of 2.6 megaton. France last nuclear test was in January 1996 before the signing on CTBT and NPT. Currently France has fewer than 300 warheads delivered by France triad nuclear system through ICBM's, Mirage 2000 bomber, and SLBM's. The People Republic of China has developed and possesses weapons of mass destruction including its chemical, biological and nuclear weapon. In October 1964, China conducted its first nuclear device test and exploded its thermonuclear test in June 1967. China lastly tested its nukes in July 1996 before the signing of CTBT and NPT. China's largest explosion was 4 megaton and currently possess 260 warheads. China has nuclear triad like USA, Russia, Britain, France, and India. China emerged as new super power through its extensive weaponry system.

Chinese missiles are; DF-5A ICBM estimated range with $13000+\mathrm{km}$, DF-31A ICBM estimated range with $11200+\mathrm{km}$, DF-31 ICBM estimated range with $7200+\mathrm{km}$, DF-4 ICBM estimated range with $5,500 \mathrm{~km}$, DF-3A IRBM estimated range with $3000+\mathrm{km}$, DF-21C MRBM estimated range with $1750+\mathrm{km}, \mathrm{DF}-21 \mathrm{MRBM}$ estimated range with $1750+\mathrm{km}$, DF-15 SRBM estimated range with $600 \mathrm{~km}$, DF-11A SRBM estimated range with $300 \mathrm{~km}$, 
DH-10 land attack cruise missile estimated range with 3000+km, JL-1 SLBM estimated range with $1770 \mathrm{~km}$, JL-2 SLBM estimated range with $7200 \mathrm{~km}$. In January 2007, China conducted an anti-satellite missile test by destroying a Chinese weather satellite by FY-1Cpolar orbit satellite of the Fengyun series. It was a successful test since 1985 as USA conducted same test destroying P78-1 satellite by using ASM-135 ASAT. Followed US satellite weaponry activities China started its ambitious anti satellite program. China is a signatory country of chemical weapons conventions since 1993. Government of China declared that it had a small amount of stockpile of chemical weapons but it had been eliminated before ratifying itself to the convention in 1997. China may have produced mustard gas, phosgene and lewisite gas agents. There was allegation of China that it supplied Albania with small stockpiles of chemical weapons in 1970's. China is a signatory of biological weapon convention (BWC) and China had extensive biological weaponry facilities until 1980.

Indian nuclear research program stated in 1944 lead by Dr. Homi Vhaba by the inauguration of institute of fundamental research. It conducted first nuclear weapon in 1974 saying smiling Buddha as code name. In 1998, India conducted its second term nuclear test by six explosion of nuclear device with yield of 24-40 kiloton, it declared as fusion test but it is controversial. India is a nuclear triad country as well; it has various form of strategic and non-strategic ballistic missile such as Prithvi-1 SRM estimated range with 150km, Prithvi-2 SRM estimated with 250-350 km, Prithvi-3 SRM estimated range with 350-600, Agni-1 short to medium range estimated range with $700-1250 \mathrm{~km}$, Agni-2 medium range estimated range with 2000-3000km, Agni-3 IRBM estimated range with 3500-5000km, Agni-4 IRBM estimated range with $4000 \mathrm{~km}$, Agni-5 intermediate to intercontinental estimated range with 5000-8000km, Agni 6 SLBM with ICBM range estimated range with $6000 \mathrm{~km}$ underdevelopment, Agni 6 ICBM estimated range with 8000-12000km.

Indian air force is capable of carries nukes through its Mirage 2000, Mig 29, Jaguars, and Tehjas fighter aircrafts. India has nuclear powered Arihant class submarine and diesel based submarine to deploy nuclear weapons in the deep-sea make India second strike capable. India extended its nuclear weapons because of Chinese aggression in 1962 Indo-Sino war, however todays India is much stronger than 1962. India has extensive research program of chemical and biological weapons but for the wellbeing of human being, it has destroyed its all forms of chemical weapon by the end of 2009.

India is a signatory country to the BWC and declared not to making biological weapons, which is harmful for human being. India is not a signatory of CTBT and NPT due to its unfair characteristics; so far, Pakistan, North Korea and Israel are not signatory of CTBT and NPT as well. In 1998, Pakistan first conducted its nuclear weapon test yield with 24-40 kiloton. Pakistan has extensive missile development program and made various forms of missile such as Abdali, Shaheen, Gahnabi, Ghori etc. that can target all over India. Pakistan nuclear weapon program is India based and its national doctrine clearly mentioned yet not victim of Indian nukes, Pakistan will use nuclear weapon against any kind war with India and Pakistan's tactical weapon is good example to use against India, where as India is same as China as no first use for nuclear deterrent with surrounding countries like Pakistan, India, North Korea and Israel. 
Pakistan nuclear program is designed against of India's conventional doctrine cold start as well which has been designed for Pakistan during war by India. Israel is the country that has not conducted any nuclear device test yet a nuclear weapons country since 1964. Israel is a non-signatory country to the CTBT and NPT and a nuclear triad country by the deliverer system of warheads by Jericho 3 missile, dolphin class submarine, and fighter planes F-151, F-161. Israel is concerned about all Arab states and their chemical and nuclear weapons; therefore, Israel has still a good resource of both chemical and biological weapons. Israel is not a signatory country to the BWC and chemical weapon convention.

According to US congress office of technology assessment Israel has undeclared offensive chemical warfare capabilities and currently maintain a biological weapon program. In 2006, North Korea declared a nuclear weapon state by conducting with yield of less than a kiloton. In 2009, North Korea conducted second nuclear test. In 2013, it conducted third nuclear test. In 2016, North Korea conducted fourth underground nuclear test. North Korea claimed its fourth test is hydrogen bomb. Fifth nuclear test was conducted by North Korea in September 2016. Yet a sanction by the western world North Korea is conducting its nuclear weapons continuously.

Estimates North Koreas missiles are $\mathrm{KN}-1$ short range anti ship cruise missile estimated range with $160 \mathrm{~km}, \mathrm{KN}-2$ Toksa, short range missile, Hwasong-5 estimated range of $330 \mathrm{~km}$, Hwasong-6 estimated range with 550-700km, Hwasong-7 estimated range with 700-800 km, Rodong 1 estimated range with 1300-1600km, Hwasonh-10 estimated range predicted 2500-4000km, Pukkusong-1 SLBM. It was reported that China and Russia contributed to develop North Korea's nuclear program. North Korea is a threat for everyone because of irresponsible and aggressive dictator Kim Jong UN.

Countries that capable of develop or obtain weapons of mass destruction
\begin{tabular}{|l|l|l|l|l|}
\hline State & Chemical & Biological & Nuclear & Missile \\
\hline USA & Yes & Yes & Yes & Yes \\
\hline Russia & Yes & Yes & Yes & Yes \\
\hline France & Yes & Yes & Yes & Yes \\
\hline Britain & Yes & & Yes & Yes \\
\hline China & Yes & Yes & Yes & Yes \\
\hline India & Yes & Yes & Yes & Yes \\
\hline North Korea & Yes & Yes & Yes & Yes \\
\hline Pakistan & Yes & Yes & Yes & Yes \\
\hline South Africa & Yes & Yes & & Yes \\
\hline Algeria & & & & \\
\hline Bulgaria & & Yes & & \\
\hline Belarus & & & & \\
\hline Cuba & & Yes & & \\
\hline Chile & Yes & & & \\
\hline
\end{tabular}




\begin{tabular}{|l|l|l|l|l|}
\hline Indonesia & Yes & & & \\
\hline Egypt & Yes & Yes & & Yes \\
\hline Ethiopia & Yes & & & \\
\hline Israel & Yes & Yes & Yes & Yes \\
\hline Iran & Yes & Yes & & Yes \\
\hline Iraq & Yes & Yes & & Yes \\
\hline Kazakhstan & & & & \\
\hline Laos & Yes & Yes & & \\
\hline Libya & Yes & Yes & & Yes \\
\hline Myanmar & Yes & & & \\
\hline Romania & & Yes & & \\
\hline South Korea & Yes & Yes & & Yes \\
\hline Sudan & Yes & & & \\
\hline Syria & Yes & Yes & & Yes \\
\hline Taiwan & Yes & Yes & & \\
\hline Thailand & Yes & & & \\
\hline Vietnam & Yes & Yes & & \\
\hline Serbia & Yes & & & \\
\hline Ukraine & & & & \\
\hline
\end{tabular}

\section{CONCLUSION}

Weapons of mass destruction has its various forms before World War 1, during World War 1 as biological and chemical weapons, during World War 2 as nuclear arsenal by the USA to Japan, conventional weapons by Japan to USA at Paarl harbour, during cold war between the USSR and the USA making allies, blocks and modern and powerful ranges of nuclear weapons by both super power; as a result other countries had encouraged to start research and development of nuclear devices due to future threat from the USA, the USSR and the Japan is the most influential example. China, India, Britain, France, Pakistan, North Korea and Israel are those countries who even not a signatory of exploded underground, sea based, on the sky nuclear test. Nuclear and radiological weapons are the most modern form of weaponry system, which can deter countries from any form of war, makes countries powerful through second-strike capabilities. However, it has negative effect as well. Maintenance of nuclear, hydrogen weapon is very expensive and its security, some countries are not really take care of its stockpiles of arsenals, which caused Chernobyl incidents in Russia, nuclear arsenals must be secured and secrets, world is violent due to terrorism, terrorist are killing people, system etc. and they have very good reason $s$ to seizes nuclear weapons from countries. Once even any short form of device goes to t6he hand of those people, they will destroy the world. Therefore, it is the duty of all nuclear powered countries to secure their weapons from terrorist is organizations. To reduce violent of nuclear balk mailing, stealing several organization, groups made such as convention of biological weapons, chemical weapons, CTBT, NPT, 
NSG(nuclear suppliers group) etc. Nuclear device used only one time after that there was no situation creates that the nuked can be used. Therefore it need to be assured that modern ware fare should not be done by nukes which will the dooms day for the human being, world as well. Therefore, the question is what is the usefulness of weapons of mass destruction in the name of nuclear, radiological, chemical, biological weapons? It is a nuclear deterrent between countries through which world can be peaceful.

\section{References}

Weapons of mass destruction. Wikipedia. Retrieved from https://en.wikipedia.org/wiki/Weapon_of_mass_destruction.

Encyclopaedia to Britannica. (2007). Weapon of mass destruction. 2007. Retrieved from https://www.britannica.com/technology/weapon-of-mass-destruction.

Organization for the Prohibition of Chemical Weapons (2017). Brief Description of Chemical weapons. 2017. Retrieved from https://www.opcw.org/about-chemical-weapons/what-is-a-chemical-weapon.

Chemical Weapon Wikipedia. Retrieved from https://en.wikipedia.org/wiki/Chemical_weapon.

Schneider. B.R. (2014, January 4). Biological weapon. Encyclopedia Britannica. Retrieved from https://www.britannica.com/technology/biological-weapon

The world's most dangerous bioweapons. (2015, April 13). Army technology. Retrieved from http://www.army-technology.com/features/featurethe-worlds-most-dangerous-bioweapons-4546207/

International committee of red cross. (2013, April 08). Chemical and biological weapons. Retrieved from https://www.icrc.org/en/war-and-law/weapons/chemical-biological-weapons

Countries with weapons of mass destruction-intelligent threat. (2000, July 29). States possessing, pursuing or Capable of Acquiring weapons of mass destruction Retrieved from https://fas.org/irp/threat/wmd_state.htm

Nuclear weapon. Wikipedia. Retrieved from https://en.wikipedia.org/wiki/Nuclear_weapon

William. H., Freudenrich. C., Fuller. J. How nuclear bomb works. How staffs works. Retrieved from https://science.howstuffworks.com/nuclear-bomb6.htm

Nuclear Weapons and the United States. Wikipedia. Retrieved by https://en.wikipedia.org/wiki/Nuclear_weapons_and_the_United_States

Keck. Z. (2015, July 28). The most dangerous nuclear weapon in america's arsenal. The national interest. Retrieved from http://nationalinterest.org/blog/the-buzz/the-most-dangerous-nuclear-weapon-americas-arsenal-13433

United States chemical weapons program. Wikipedia. Retrieved from https://en.wikipedia.org/wiki/United_States_chemical_weapons_program

Russia and weapons of mass destruction. Wikipedia. Retrieved from https://en.wikipedia.org/wiki/Russia_and_weapons_of_mass_destruction

Britain and weapons of mass destruction. Wikipedia. Retrieved from https://en.wikipedia.org/wiki/United_Kingdom_and_weapons_of_mass_destruction

France and weapons of mass destruction. Wikipedia. Retrieved from https://en.wikipedia.org/wiki/France_and_weapons_of_mass_destruction

China and weapons of mass destruction. Wikipedia. Retrieved by https://en.wikipedia.org/wiki/China_and_weapons_of_mass_destruction

2007 Chinese anti satellite missile test. Wikipedia. Retrieved by https://en.wikipedia.org/wiki/2007_Chinese_anti-satellite_missile_test

India and weapons of mass destruction. Wikipedia. Retrieved from https://en.wikipedia.org/wiki/India_and_weapons_of_mass_destruction

Pakistan and weapons of mass destruction. Wikipedia. Retrieved by https://en.wikipedia.org/wiki/Pakistan_and_weapons_of_mass_destruction

Israel and weapons of mass destruction. Wikipedia. Retrieved by https://en.wikipedia.org/wiki/Israel_and_weapons_of_mass_destruction

North Korea and weapons of mass destruction. Wikipedia. Retrieved from https://en.wikipedia.org/wiki/North_Korea_and_weapons_of_mass_destruction 